\title{
OPTIMUM DESIGN OF DEEP DRAWING TOOLS ANd Process Parameters by APPLying NONCONVENTIONAL METHODS
}

\author{
BRABIE, G.; NANU, N. \& RADU, M.
}

Abstract: The most frequent defects generated by cold plastic forming in the parts made from metal sheets are caused by the springback phenomenon. The springback effects mainly determine the decrease of accuracy of the drawn part by changing its shape and dimensions after the tool removing. The present paper analyses the results obtained from the application of the LMecA /Taguchi/Neural Network/Fuzzy Logic methods in the designing phase of the drawing processes in order to increase the accuracy of the parts made from metal sheets by reducing or eliminating the springback effects. The optimization system based on the above mentioned methods performs the reduction of the springback intensity by an optimum design of the drawing tools geometry and process parameters.

Key words: Springback, Hemispherical draw parts, Tool correction, Optimization system
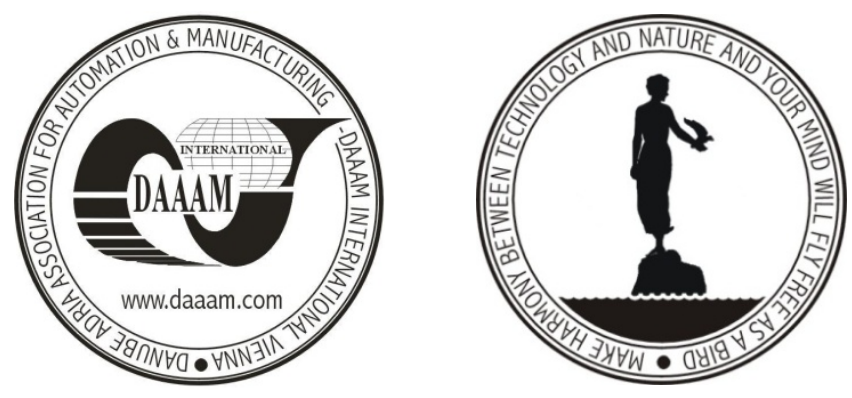

Authors' data: Prof. Brabie, G[heorghe]; Nanu, N[icolaie]; Radu, M[ioara], University of Bacau, 157 Marasesti street, 600115, Bacau, RO, g-brabie@ub.ro, nicu.nanu@ub.ro,radu_mioara_elena@yahoo.com

This Publication has to be referred as: Brabie, G[heorghe]; Nanu, N[icolaie] \& Radu, M[ioara] (2008). Optimum Design of Deep Drawing Tools and Process Parameters by Applying Nonconventional Methods, Chapter 13 in DAAAM International Scientific Book 2008, pp. 147-160, B. Katalinic (Ed.), Published by DAAAM International, ISBN 978-3-901509-66-7, ISSN 1726-9687, Vienna, Austria DOI:10.2507/daaam.scibook.2008.13 